\title{
NIALAMIDE AS A "STEROID SPARING" AGENT IN THE TREATMENT OF RHEUMATOID ARTHRITIS
}

\author{
BY
}

\author{
V. WRIGHT, W. C. WALKER, AND E. A. M. WOOD \\ From the University Departments of Clinical Medicine and Psychiatry, \\ The General Infirmary, Leeds
}

The dangers of corticosteroid therapy in patients with rheumatoid arthritis make valuable any regime which would enable the effective dosage to be reduced. Some clinical reports have suggested that the introduction of a monoamine oxidase inhibitor to a scheme of corticosteroid dosage might result in a "steroid sparing" effect and thus improve the apparent therapeutic ratio of the steroid (Scherbel, 1957, 1958; Banghart, 1958). Several uncontrolled studies have been reported. Gillhespy (1961) used nialamide in patients with moderately severe rheumatoid arthritis who had been under continuous treatment with steroids, and this enabled a subsequent reduction in dosage to be made in 83 per cent. without clinical deterioration. Other authors (Pratesi and Muzzolini, 1959; Cecchi and Ferraris, 1959; Sales-Sales, 1961; Krammer, 1961; Moretti and Staeffen, 1961) similarly claimed that arthritis was ameliorated with the aid of nialamide. All these workers believed that their results were related to a pharmacological effect either on the biochemistry of rheumatoid arthritis or on the metabolism of steroids.

However, it is known that nialamide has an antidepressive action (Scherbel and Harrison, 1959) and it is possible that an apparent "steroid sparing" effect might be due to the production of mood elevation and increased pain tolerance rather than to an interaction with steroids. A double-blind controlled trial has therefore been performed in patients with rheumatoid arthritis receiving corticosteroids to answer the questions:

(1) Does nialamide have a "steroid sparing" effect?

(2) If so, is this a real effect on articular status or is it associated with the antidepressive action of the drug?

\section{Material and Methods}

Thirty consecutive patients with definite rheumatoid 8 arthritis by the diagnostic criteria of the American Rheumatism Association (Ropes, Bennett, Cobb, Jacox, and Jessar, 1959) were admitted to the trial from those attending the outpatient clinic. They were selected on the basis of being able and willing to participate in the study, having been on a constant dose of corticosteroid equivalent to $7.5 \mathrm{mg}$. or more of prednisolone daily for a preceding period of at least 6 months, not having received gold or antimalarial drug therapy in that period, and having no history of jaundice.

Arthritic and psychiatric assessments were made immediately before the start of the trial and at periods of 4 and 8 weeks during the trial. At each assessment the following parameters were measured: patient's assessment of fitness in percentage; functional status in five grades, varying from normal (1) to complete crippling (5); the mean strength of two grips of each hand; the number of joints showing two of the signs, tenderness, swelling, and limitation of movement; haemoglobin level; erythrocyte sedimentation rate; serum glutamic

COMPARISON OF TREAФMEI

\begin{tabular}{|c|c|c|c|c|c|c|c|c|c|}
\hline \multirow{2}{*}{ Treatment } & \multicolumn{7}{|c|}{ Clinical Particulars } & & న్ల \\
\hline & Total & Males & $\begin{array}{c}\text { Mean Age } \\
(\mathrm{yrs})\end{array}$ & $\begin{array}{c}\text { Mean } \\
\begin{array}{c}\text { Duration of } \\
\text { Arthritis } \\
(\mathrm{yrs})\end{array}\end{array}$ & $\begin{array}{c}\text { Pred- } \\
\text { nisolone }\end{array}$ & $\begin{array}{c}\text { Triamcino- } \\
\text { lone }\end{array}$ & $\begin{array}{c}\text { Methyl } \\
\text { Prednisolone }\end{array}$ & $\begin{array}{l}\text { Mean } \\
\text { No. }\end{array}$ & $\begin{array}{l}\text { Squace Roc } \\
\text { Transffmati }\end{array}$ \\
\hline Placebo & 13 & 2 & $51 \cdot 4$ & $15 \cdot 2$ & 11 & 2 & 0 & $16 \cdot 4$ & $\underset{0}{3}$ \\
\hline Nialamide $\ldots$ & 13 & 1 & $56 \cdot 2$ & $10 \cdot 1$ & 11 & 1 & 1 & $17 \cdot 5$ & $4 \sqrt{2}$ \\
\hline
\end{tabular}


oxaloacetic transaminase (s.g.o.t.), and serum glutamic pyruvic transaminase (s.g.p.t.).

Psychiatric assessment was undertaken by one of us (E.A.M.W.) in interviews with the patient and where possible with relatives. Particular attention was paid to the presence or absence of depression and to its severity. In view of the known ability of steroids to produce affective disturbance (Bleuler, 1954), any relationship between the onset and duration of depressive symptoms and the administration of steroids was noted. In interviews at Week 4 and Week 8 , further assessments were undertaken, and the improvement or deterioration in the affective state was recorded in three grades from slight (1) to marked (3).

The patients were treated over two consecutive 4-week periods. The design of the trial is illustrated in the Figure.

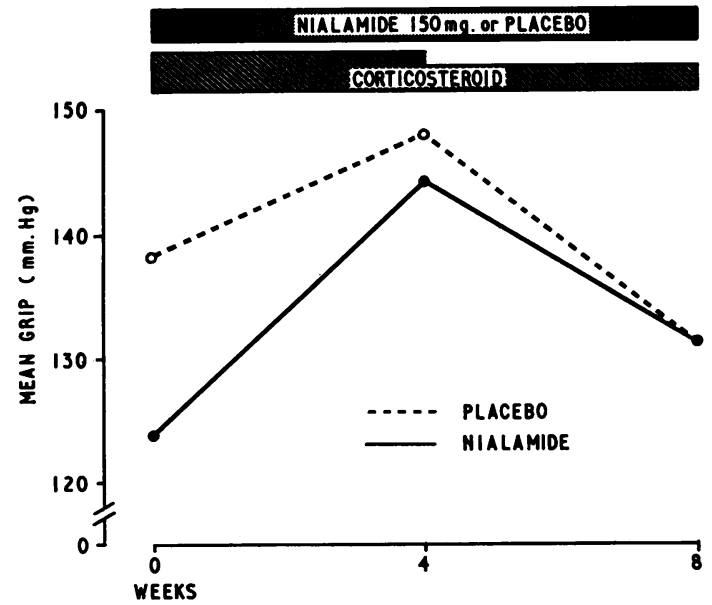

Figure.-Dosage during 8 weeks of trial, showing results of tests of strength of grip.

During the first period they received the dose of corticosteroid on which they had been maintained for the previous 6 months, together with nialamide $50 \mathrm{mg}$. three times daily or placebo tablets. During the second period the corticosteroid dose was reduced by one-third and the same dose of nialamide or placebo was continued. The trial was conducted in a double-blind manner, patients being allocated from a randomized master sheet held by the pharmacist. The randomization was unknown to any of the physicians making assessments before the conclusion of the trial. Throughout the trial no physiotherapy, intra-articular injections, or any other change of treatment was permitted.

\section{Withdrawals}

Four patients were withdrawn from the trial-two receiving nialamide and two receiving placebo. Of the two on nialamide, one woman aged 60 years suffered severe postural dizziness, and another woman aged 64 years made a suicidal attempt by taking a small overdose of barbiturate and was admitted to hospital. Of the two receiving placebo, one woman aged 69 years developed non-postural dizziness and vomiting, and another woman aged 65 was withdrawn as she failed to attend for assessment at Week 8 .

\section{Composition of Groups}

The characteristics of the two groups of patients are shown in Table 1.

There was no significant difference in any aspect, although the mean duration of arthritis in the group treated with the active drug was less than in those treated with the placebo. Mean grip strength was greater in patients receiving the placebo than in those receiving active drug, and the mean erythrocyte sedimentation rate was higher in the former, but these differences were not significant. The majority of patients had been receiving prednisolone; three were taking triamcinolone, and one methyl prednisolone.

\section{Results}

Table II (overleaf) shows changes in the parameters assessed between Weeks 0 and 4 and Weeks 0 and 8.

\section{Functional Status}

Most patients retained their original status over the whole period. Two on placebo and three on nialamide showed deterioration by the end of the trial (Table II).

\section{Fitness}

There was a slight increase in the mean percentage in both groups at Week 4 and a deterioration at Week 8. These changes were not significantly related to treatment.

ROUPS AT START OF TRIAL

\begin{tabular}{|c|c|c|c|c|c|c|c|c|c|c|c|c|c|}
\hline \multicolumn{8}{|c|}{ Arthritic Status } & \multicolumn{6}{|c|}{ Blood Tests } \\
\hline \multicolumn{3}{|c|}{ Mean Strength of Grip (mm. Hg) } & \multicolumn{5}{|c|}{ Function (Grade) } & \multirow{2}{*}{$\begin{array}{c}\text { Mean } \\
\text { Hb } \\
\text { (per cent.) }\end{array}$} & \multirow{2}{*}{$\underset{\mathrm{mm} . / 1 \mathrm{st} \mathrm{hr})}{\text { Mean E.S.R. }}$} & \multicolumn{4}{|c|}{ Differential Agglutination Test } \\
\hline Right & Left & Overall & 1 & 2 & 3 & 4 & 5 & & & Positive & Negative & $\begin{array}{l}\text { Mean } \\
\text { Titre }\end{array}$ & $\begin{array}{c}\operatorname{logs} \\
\text { (base 2) }\end{array}$ \\
\hline $134 \cdot 9$ & $141 \cdot 2$ & $138 \cdot 0$ & 1 & 7 & 4 & 1 & 0 & $88 \cdot 9$ & $39 \cdot 8$ & 9 & 4 & 229 & $5 \cdot 7$ \\
\hline $126 \cdot 5$ & $120 \cdot 7$ & $123 \cdot 6$ & 2 & 6 & 5 & $\mathbf{0}$ & 0 & $87 \cdot 4$ & $28 \cdot 5$ & 8 & 5 & 270 & $5 \cdot 5$ \\
\hline
\end{tabular}


Number of Affected Joints

There was a tendency for the number of affected joints to increase during the trial in both groups. Tests of significance performed on the square root transformation of numbers of affected joints showed no significant difference between the treatments.

\section{Strength of Grip}

The changes in strength of grip are shown in the Figure, in which mean values for the nialamide and placebo groups are plotted against time.

The placebo mean at Week 0 was rather higher than the nialamide mean, but not significantly so. At Weeks 4 and 8 placebo and nialamide means were very much the same, indicating a greater rise in patients on nialamide to the maximum at Week 4, and very similar falls in mean grip of both groups at Week 8. Changes in mean grip between Week 0 and Week 4 revealed a significant increase in both groups. The increase was larger by $10.5 \mathrm{~mm}$. $\mathrm{Hg}$ in the nialamide group, but this value was less than the least significant value at the $P=0.05$ level $(12.6 \mathrm{~mm}$. $\mathrm{Hg})$. Between Week 4 and Week 8 there were significant falls in mean grip in both groups, the fall in the nialamide group being not significantly different from that in the placebo group.

\section{Haemoglobin}

For technical reasons haemoglobin assessments were not always available at each review and only those patients with a complete set of data have been analysed (eleven patients receiving placebo and nine receiving nialamide). There were no significant changes and no significant treatment effects.

\section{Erythrocyte Sedimentation Rate}

This tended to decrease in the first 4 weeks and to increase rather more in the second 4 weeks. In the group treated with nialamide there was a greater rise $(18 \mathrm{~mm} . / 1 \mathrm{st} \mathrm{hr})$ than in the group treated with placebo.

\section{Psychiatric Assessment}

The changes in the psychiatric assessment have been treated as scores for the purposes of statistical analysis and mean scores are given in Table II. They increased in both groups during the first 4 weeks, indicating a general improvement. The improvement was rather larger among patients on nialamide, but the difference did not quite reach its least significant value. There was a further small improvement among placebo patients during the last 4 weeks, but none among patients receiving nialamide.

\section{Relationship between Psychiatric and Arthritic} Assessment

The correlations between changes in the psychiatric assessment and arthritic status are shown in Table III (opposite). There was no correlation with the number of affected joints, haemoglobin, or erythrocyte sedimentation rate.

TABLE II

CHANGES DURING COURSE OF TRIAL

\begin{tabular}{|c|c|c|c|c|c|c|c|c|c|c|c|}
\hline & \multirow{2}{*}{\multicolumn{3}{|c|}{ Variate }} & \multicolumn{4}{|c|}{ Between Week 0 and Week 4} & \multicolumn{4}{|c|}{ Between Week 0 and Week 8} \\
\hline & & & & \multirow{2}{*}{\begin{tabular}{|c|}
$\begin{array}{c}\text { Placebo } \\
\text { Group }\end{array}$ \\
1 \\
$(7 \cdot 7 \%)$ \\
12 \\
$(92 \cdot 3 \%)$ \\
0 \\
$(0 \%)$
\end{tabular}} & \multirow{2}{*}{$\begin{array}{c}\begin{array}{c}\text { Nialamide } \\
\text { Group }\end{array} \\
\begin{array}{c}1 \\
(7 \cdot 7 \%) \\
11 \\
(84 \cdot 6 \%) \\
1 \% \\
(7 \cdot 7 \%)\end{array}\end{array}$} & \multirow{2}{*}{$\begin{array}{r}\begin{array}{r}\text { Difference } \\
\text { Nialamide } \\
\text {-Placebo }\end{array} \\
0 \cdot 0 \% \\
-7 \cdot 7 \% \\
+7 \cdot 7 \%\end{array}$} & \multirow[t]{2}{*}{\begin{tabular}{|c|} 
Least \\
Significant \\
Difference \\
$(\mathbf{P}=0.05)$ \\
\end{tabular}} & \multirow{2}{*}{\begin{tabular}{|c|}
$\begin{array}{c}\text { Placebo } \\
\text { Group }\end{array}$ \\
$\begin{array}{c}1 \\
(7 \cdot 7 \%) \\
10 \\
(76.9 \%) \\
2 \% \\
(15 \cdot 4 \%)\end{array}$ \\
\end{tabular}} & \multirow{2}{*}{\begin{tabular}{|c|}
$\begin{array}{c}\text { Nialamide } \\
\text { Group }\end{array}$ \\
0 \\
$(0 \cdot 0 \%)$ \\
10 \\
$(76.9 \%)$ \\
$3 \%$ \\
$(23 \cdot 1 \%)$
\end{tabular}} & \multirow{2}{*}{\begin{tabular}{|c|}
$\begin{array}{r}\text { Difference } \\
\text { Nialamide } \\
\text { - Placebo }\end{array}$ \\
$-7 \cdot 7 \%$ \\
$0.0 \%$ \\
$+7 \cdot 7 \%$ \\
\end{tabular}} & \multirow[t]{2}{*}{\begin{tabular}{|l|}
\multicolumn{1}{|c|}{ Least } \\
Significant \\
Difference \\
$(\mathrm{P}=0.05)$
\end{tabular}} \\
\hline Functional Status & $\begin{array}{l}\text { Improved } \\
\text { No Change } \\
\text { Deteriorated }\end{array}$ & $\begin{array}{l}\cdots \\
\cdots \\
\cdots\end{array}$ & 一. & & & & & & & & \\
\hline Fitness (per cent.) & $\cdots$ & $\cdots$ & .. & $+2 \cdot 7$ & $+1 \cdot 5$ & $-1 \cdot 2$ & $11 \cdot 5$ & $-2 \cdot 7$ & $-3 \cdot 8$ & $-1 \cdot 1$ & $13 \cdot 8$ \\
\hline doint & $\begin{array}{l}\text { Numbers } \\
\text { Square Root }\end{array}$ & Trans & ormation & $\begin{array}{r}+0.46 \\
+0.02 \\
\end{array}$ & $\begin{array}{r}+0.62 \\
+0.07 \\
\end{array}$ & $+\overline{0} .05$ & $\overline{0 \cdot 20}$ & $\begin{array}{r}+0.62 \\
+0.04 \\
\end{array}$ & $\begin{array}{r}+0.69 \\
+\quad 0.15 \\
\end{array}$ & $+\overline{0} \cdot 11$ & $\overline{0.31}$ \\
\hline $\begin{array}{l}\text { Strength of Grip } \\
\text { (mm. Hg) }\end{array}$ & $\begin{array}{l}\text { Left } \ldots \\
\text { Right } \ldots \\
\text { Overall }\end{array}$ & $\begin{array}{l}\ldots \\
\cdots \\
\cdots\end{array}$ & $\begin{array}{l}. \\
\cdots \\
\cdots\end{array}$ & $\begin{array}{l}+4 \cdot 8 \\
+15 \cdot 2 \\
+10 \cdot 0\end{array}$ & $\begin{array}{l}+16 \cdot 8 \\
+24 \cdot 1 \\
+20 \cdot 5\end{array}$ & $\begin{array}{l}+12 \cdot 0 \\
+8 \cdot 9 \\
+10 \cdot 5\end{array}$ & $\begin{array}{l}17 \cdot 8 \\
17 \cdot 8 \\
12 \cdot 6\end{array}$ & $\begin{array}{l}-10 \cdot 0 \\
=4 \cdot 1 \\
-7 \cdot 0\end{array}$ & $\begin{array}{l}+4 \cdot 1 \\
+10 \cdot 8 \\
+\quad 7 \cdot 5\end{array}$ & $\begin{array}{l}+14 \cdot 1 \\
+14.9 \\
+14.5\end{array}$ & $\begin{array}{l}21 \cdot 5 \\
21 \cdot 5 \\
15 \cdot 2\end{array}$ \\
\hline Blood Tests & $\begin{array}{l}\text { Hb }(\%) \\
\text { E.S.R. }(\mathrm{mm} . /\end{array}$ & (ist hr) & $\because$. & $\begin{array}{l}-0.6 \\
-9.3\end{array}$ & $\begin{array}{l}+1 \cdot 9 \\
-3 \cdot 2\end{array}$ & $\begin{array}{l}+2 \cdot 5 \\
+6 \cdot 1\end{array}$ & $\begin{array}{r}8 \cdot 6 \\
16 \cdot 8\end{array}$ & $\begin{array}{l}-2 \cdot 7 \\
-6 \cdot 8\end{array}$ & $\begin{array}{l}+1 \cdot 0 \\
+11 \cdot 2\end{array}$ & $\begin{array}{l}+3 \cdot 7 \\
+18 \cdot 0\end{array}$ & $\begin{array}{r}9 \cdot 1 \\
18 \cdot 7\end{array}$ \\
\hline Psychiatric & - & & $\cdots$ & +0.4 & $+1 \cdot 3$ & +0.9 & $1 \cdot 0$ & $+0 \cdot 7$ & $+1 \cdot 2$ & $+0 \cdot 5$ & 0.9 \\
\hline
\end{tabular}


TABLE III

CORRELATION COEFFICIENTS BETWEEN PSYCHIATRIC CHANGE AND CHANGE IN OTHER PARAMETERS

\begin{tabular}{|c|c|c|c|c|}
\hline Parameter & & Weeks & $\begin{array}{l}\text { Placebo } \\
\text { Group }\end{array}$ & $\underset{\text { Group }}{\text { Nialamide }}$ \\
\hline Fitness (per cent.) .. & $\cdots$ & $\begin{array}{l}0-4 \\
0-8\end{array}$ & $\begin{array}{l}+0.75 t \\
+0.66^{*}\end{array}$ & $\begin{array}{l}+0.77 \dagger \\
+0.55\end{array}$ \\
\hline Strength of Grip & $\cdots$ & $\begin{array}{l}0-4 \\
0-8\end{array}$ & $\begin{array}{l}-0.12 \\
-0.08\end{array}$ & $\begin{array}{l}+0 \cdot 70^{*} \\
+0.16\end{array}$ \\
\hline No. of Affected Joints & .. & $\begin{array}{l}0-4 \\
0-8\end{array}$ & $\begin{array}{l}-0.03 \\
-0.01\end{array}$ & $\begin{array}{l}-0 \cdot 27 \\
-0 \cdot 29\end{array}$ \\
\hline Hb (per cent.) & $\ldots$ & $\begin{array}{l}0-4 \\
0-8\end{array}$ & $\begin{array}{l}-0 \cdot 13 \\
+0.37\end{array}$ & $\begin{array}{l}-0 \cdot 28 \\
+0 \cdot 11\end{array}$ \\
\hline E.S.R. (mm./1st hr) & $\ldots$ & $\begin{array}{l}0-4 \\
0-8\end{array}$ & $\begin{array}{l}-0.01 \\
-0.25\end{array}$ & $\begin{array}{l}-0.06 \\
-0.30\end{array}$ \\
\hline
\end{tabular}

* indicates the observed correlation coefficient was significantly different from zero at the $P=0.05$ level.

+ indicates the same at the $P=0.01$ level.

A striking correlation at the $P=0.01$ level existed between psychiatric change and change in the patients' estimation of fitness in both those receiving placebo and those receiving nialamide in the first 4 weeks. A similar trend was shown over the whole period, which was significant at the $P=0.05$ level in the placebo group, but did not reach significance in the nialamide group. A significant correlation of strength of grip with psychiatric change was present in the first 4 weeks in those receiving nialamide.

\section{Complications}

Complications (including those necessitating withdrawal from the trial) are shown in Table IV. Of the nine patients experiencing untoward effects during the administration of nialamide, three complained of nausea, but this was also present in two patients receiving placebo. Postural dizziness and insomnia were side-effects found only in patients receiving nialamide. Other symptoms in patients receiving placebo were headache for the first few days in one, a feeling of drowsiness in the first few days in a second, and pain in the limbs, faintness, and nightmares in a third.

TABLE IV

UNTOWARD EFFECTS DURING THE TRIAL OF NIALAMIDE

\begin{tabular}{|c|c|c|c|c|c|c|}
\hline \multirow{2}{*}{ Treatment } & \multicolumn{6}{|c|}{ Side-Effects (No. of Cases) } \\
\hline & Nausea & $\begin{array}{c}\text { Dizzi- } \\
\text { ness }\end{array}$ & $\begin{array}{c}\text { Insom- } \\
\text { nia }\end{array}$ & $\begin{array}{l}\text { Suicidal } \\
\text { Attempt }\end{array}$ & Other* & Total \\
\hline $\begin{array}{ll}\text { Placebo } & . . \\
\text { Nialamide } & . .\end{array}$ & 2 & $\begin{array}{c}1 \\
2 \\
\text { (pos- } \\
\text { tural) }\end{array}$ & $\overline{3}$ & $\overline{1}$ & 3 & $\begin{array}{l}6 \\
9\end{array}$ \\
\hline
\end{tabular}

* see text.

There was no evidence of liver damage throughout the trial. The s.g.o.t. and s.g.p.t. levels remained within the normal range in all patients throughout. Over the whole period there was a rise in s.g.o.t. levels in the nialamide group from a mean value of $17 \cdot 4$ units to $20 \cdot 5$ units, compared with a fall from $18 \cdot 5$ units to $17 \cdot 8$ units for the placebo group, but these differences were not significant. There was a similar small rise in the mean s.g.p.t. level from $17 \cdot 1$ units to $18 \cdot 5$ units in the nialamide group, and in the placebo group the mean value was the same (15.3 units) at the beginning and end of the trial, but again these differences were not significant.

\section{Discussion}

Any method permitting reduction of steroid dosage in patients with rheumatoid arthritis without increased activity is worthy of investigation. It is important, therefore, to examine the claim that nialamide acts in such a manner.

Gillhespy (1961) has postulated that monoamine oxidase inhibitors may compensate for biochemical disturbances recorded in rheumatoid arthritis (Michotte, 1958; Schmid, Scheiffarth, and Zicha, 1959) or may delay hepatic inactivation of cortisone and related compounds. However, it is well known that nialamide may produce elevation of mood (Scherbel and Harrison, 1959), and it may be that the apparent "steroid sparing" effect of nialamide is due to this indirect action which enables patients to tolerate the pain of the arthritis better and thus allow a decrease of steroid dosage.

\section{Effect on Arthritis}

There were no significant differences between the effects of treatment with nialamide and placebo in the parameters measured over the trial period. Strength of grip showed a marked placebo effect in the first 4 weeks, and during the period of steroid reduction a significant fall, but there was no evidence to suggest that nialamide did anything to compensate for the decrease in strength of grip which followed reduction in dosage.

\section{Psychiatric Assessment}

One of the outstanding features of this investigation was the number of patients who exhibited depressive aspects of their illness on careful psychiatric evaluation. Out of the thirty patients only two experienced no depressive symptoms.

In both groups a number of patients experienced definite improvement in depressive symptoms during the total period of observation (eight receiving nialamide, five receiving placebo).

Over the whole 8-week period no significant 
difference between placebo and nialamide was demonstrated, but the groups were not matched initially with respect to their psychiatric state, as the trial was not primarily concerned with the absolute effect of nialamide in relieving depressive symptoms. The only two patients who showed no depressive symptoms were included by chance in the nialamide group. Furthermore, in one case, there was a definite relationship between the duration of depressive symptoms and the administration of steroids. This patient was included in the placebo group and showed an improvement in her symptoms in the second 4-week period, i.e. after the reduction in the steroid dosage. It seems likely, therefore, that the results do less than justice to the ability of nialamide to relieve the depressive symptoms so frequently found in this group of patients.

\section{Relationship between Psychiatric and Arthritic Change}

It is of great interest that there was a significant correlation between changes in psychiatric assessment and subjective arthritic status, these respective changes being ascertained independently by the psychiatrist and physician. There was no such correlation with assessments which were objective.

Strength of grip, which might have been expected to show a correlation with the psychiatric assessment in view of the known importance of psychological factors in limiting the expression of human strength (Ikai and Steinhaus, 1961), showed a significant correlation only in the nialamide group and only in the first 4 weeks.

\section{Toxicity}

Attention was paid to the possibility of liver damage in view of the reports concerning iproniazid and other monoamine oxidase inhibitors by Popper (1958) and Holdsworth, Atkinson, and Goldie (1961), who indicated that this complication could be fatal. The only side-effect with nialamide which was sufficiently serious to necessitate withdrawal from this trial was postural dizziness in one patient.

\section{Conclusions}

Before recommending the addition of another potentially dangerous drug to the list of those already employed in the treatment of rheumatoid arthritis, it is essential that there be evidence of real benefit to the patient. It would appear from the present study that any "steroid sparing" action on the part of nialamide does not act by means of a direct biochemical mechanism in which it interacts with corticosteroids, but rather by an elevation of mood and increased tolerance of pain.

We have been impressed by the high incidence of depression in subjects with chronic rheumatoid arthritis. This is not infrequently overlooked and we believe that more attention needs to be paid to this factor in these patients. It is for a well-defined indication such as this that antidepressive drugs should be used.

\section{Summary}

The efficacy of nialamide as a "steroid sparing" agent in the treatment of rheumatoid arthritis has been studied in thirty patients by a double-blind controlled trial.

The patients received $50 \mathrm{mg}$. nialamide three times daily, or a placebo, in addition to their normal dose of corticosteroid for 4 weeks; the dose of corticosteroid was then reduced by one-third and nialamide or the placebo continued in the same dose. Arthritic and psychiatric assessments were made at the beginning of the trial and at the end of each 4-week period.

There was no evidence that nialamide acted as a steroid sparing agent. A striking correlation $8 \overrightarrow{0}$ was found, however, between psychiatric and subjective arthritic changes, and it is suggested that any apparent steroid sparing action reported by others? may be due to elevation of mood rather than to a direct biochemical interaction.

We are grateful to Prof. S. J. Hartfall, who afforded facilities for this study, and to Mr. P. R. D. Avis, who gave valuable statistical assistance. A generous supply of nialamide was provided by Dr. J. Goulton, of Harvey Pharmaceuticals, Ltd. We have also appreciated the help of Mr. N. W. Blacow, Senior Pharmacist of the General Infirmary at Leeds.

\section{REFERENCES}

Banghart, H. (1958). J. clin. exp. Psychopath., 19 (Suppl. 1), p. 114.

Bleuler, M. (1954). Quoted in Mayer-Gross, W., Slater, E., and Roth, M. (1960). "Clinical Psychiatry", 2nd ed., pp. 236 and 328. Cassell, London.

Cecchi, E., and Ferraris, F. (1959). Minerva med., 50, 4455.

Gillhespy, R. O. (1961). Med. Observ. chemother. Rev., 2, 250 .

Holdsworth, C. D., Atkinson, M., and Goldie, W. (1961). Lancet, $2,621$.

Ikai, M., and Steinhaus, A. H. (1961). J. appl. Physiol., $16,157$. 
Krammer, F. (1961). Wien. med. Wschr., 111, 353.

Michotte, L. J. (1958). J. belge Méd. phys. Rhum., $13,183$.

Moretti, G. F., and Staeffen, J. (1961). Sem. Hôp. Paris, 37, 989.

Popper, H. (1958). J. Amer. med. Ass., 168, 2235.

Pratesi, G., and Muzzolini, M. (1959). Minerva med., 50, 4447.

Ropes: M. W., Bennett, G. A., Cobb, S., Jacox, R., and Jessar, R. A. (1959). Ann. rheum. Dis., 18, 49.

Sales-Sales, E. (1961). Med. y Cienc. Afines (Colombia), 12, 3.

Scherbel, A. L. (1957). Cleveland clin. Quart., 24, 90. (1958). J. clin. exp. Psychopath., 19, Suppl. 1, p. 118.

and Harrison, J. W. (1959). Ann. N.Y. Acad. Sci., $80,820$.

Schmid, E., Scheiffarth, F., and Zicha, L. (1959). Lancet, 2, 354.

\section{Nialamide comme agent "économe de steroides" dans le traitement de l'arthrite rhumatismale}

\section{RÉSUMÉ}

L'efficacité du nialamide comme agent "économe de stéroïdes" dans le traitement de l'arthrite rhumatismale fut étudié chez trente malades par un double-blind essai thérapeutique.

Les malades recevaient $50 \mathrm{mg}$. de nialamide trois fois par jour, ou une substance inerte de contrôle, en plus de leur dose normale de corticostéroides pendant 4 semaines; ensuite la dose de corticostéroïde fut diminuée d'un tiers et le nialamide ou la substance inerte continués à la même dose. Des évaluations de l'arthrite et de l'état mental furent effectuées au début de l'essai at à la fin de chaque période de 4 semaines.

On ne trouva pas de preuves que le nialamide agisse come agent économe de stéroïdes. On observa toutefois une correlation frappante entre les altérations psychiatriques et les altérations arthritiques subjectives et on pense que toute action apparente d'économie de stéroïdes, rapportée par d'autres auteurs, serait due à une euphorie plutôt qu'à une interaction biochimique directe.

Nialamida como agente de "ahorro de esteroides" en el tratamineto de la artritis reumatoide

\section{SUMARIO}

La eficacia de la nialamida como agente de "ahorro de esteroides" en el tratamiento de la artritis reumatoide fué estudiada en treinta enfermos en un ensayo terapéutico por el método de double blind.

Los enfermos recibieron $50 \mathrm{mg}$. de nialamida tres veces al día o un producto inerte de control, por encima de su dosis normal de corticosteroides, durante cuatro semanas; luego la dosis de corticosteroide fué disminuida de una tercera sin cambiar la de la nialamida o del producto inerte. Se efectuaron valoraciones de la artritis y del estado mental al principio del ensayo y al cabo de cada período de 4 semanas.

No se encontraron datos indicando que la nialamida obre como agente de ahorro de esteroides. Se observó sin embargo una correlación asombrosa entre las alteraciones psiquiátricas y las artríticas sujetivas y se piensa que toda acción aparente de ahorro de esteroides, relatada por otros autores, se debe a un efecto de euforia más bien que a una acción bioquímica directa. 